\title{
The Effect of Casting Technology on Fe Intermetallic Phases in Al-Si Cast Alloys
}

Lenka Kuchariková, Eva Tillová, Juraj Belan, Milan Uhríčik

Faculty of Mechanical Engineering, University of Žilina. Univerzitná 8215/1, 01026 Žilina. Slovakia. E-mail: lenka.kucharikova@fstroj.uniza.sk, eva.tillova@fstroj.uniza.sk,juraj.belan@fstroj.uniza.sk,milan.uhricik@fstroj.uniza.sk

The most widely used technologies of founding Al-Si cast alloys are gravitation and semi-centrifugal casting, casting under pressure and so on. The contribution deals with influence of different casting method on changes of Fe intermetallic phases. Casting into metallic mould and sand mould were used for experimental work for comparison Fe-rich formation. Fe is a common impurity that leads to the formation of complex Fe-rich intermetallic phases. The dominant phase is plate-shaped $\mathrm{Al}_{5} \mathrm{FeSi}$. These phases are unwaited, because reduce properties of aluminium casting. The experimental materials have most common addition $\mathrm{Mn}$. The addition of $\mathrm{Mn}$ may reduce $\mathrm{Al}_{5} \mathrm{FeSi}$ phase and promote formation $\mathrm{Fe}$-rich phases $\mathrm{Al}_{15}\left(\mathrm{FeMn}_{3} \mathrm{Si}_{2}\right.$ in ,skeleton like“ or „Chinese script” form. This knowledge was confirmed. The present study is a part of larger research project.

Keywords: Aluminium Alloys, Casting Technology, Fe Intermetallic Phases, Quantitative Assesment

\section{Acknowledgement}

The authors acknowledge the financial support of the projects VEGA No. 1/0533/15, KEGA No. 044ŽU-4/2014 and European Union - the Project ITMS 26110230117.

\section{References}

[1] GRAYSON, G. N., SCHAFFER, G. B., GRIFFITHS, J. R. (2007). Observations of oxide films on fatigue fracture surfaces of a sintered 2xxx series aluminium alloy. In: Materials Science and Engineering, A 454-455, pp. 99103.

[2] WANG, E.R., HUI, X.D., WANG, S.S., ZHAO, Y.F., CHEN, G.L. (2010). Improved mechanical properties in cast $\mathrm{Al}-\mathrm{Si}$ alloys by combined alloying of $\mathrm{Fe}$ and $\mathrm{Cu}$. In: Materials Science and Engineering A 527, pp. 7878-7884

[3] SAMUEL, A. M., SAMUEL, F. H., DOTY, H. W. (1996). Observations on the formation of b-Al5FeSi phase in 319 type Al-Si alloys. In: Journal of Materials Science, Vol. 31, pp. 5529-5539.

[4] UHRÍČIK, M., PALČEK, P., SOVIAROVÁ, A., SNOPIŃSKI, P. (2014). Change of internal friction on aluminium alloy with $10.1 \% \mathrm{Mg}$ dependence on the temperature. In: Manufacturing technology, Vol. 14, No. 3, pp. 467- 470

[5] SRIVATSAN, T. S., GURUPRASAD, G., VIJAY VESUDEVAN, K. (2008). The quasi static deformation and fracture behavior of aluminum alloy 7150. In: Materials and Design, Vol. 29, pp. 742-751

[6] MILLER W.S., ZHUANG L., BOTTEMA J., WITTEBROOD A. J., SMET P. DE, HASZLER A., VIEREGGE A. (2000). Recent development in aluminium allos for the automotive industry. In: Materials Science and Engineering, A280, pp. 37-49

[7] HURTAlOVÁ, L., TILlOVÁ, E., CHALUPOVÁ, M., BELAN, J., VAŠKO, A. (2014). Microstructure control of secondary A 231 cast alloy used in automotive industry. In: Manufacturing technology, Vol. 14, No. 3, pp. 326-333.

[8] RIOS, C. T., CARAM, R., BOLFARINI, C., BOTTA, W.J., KIMINAMI, C.S. (2003). Intermetallic compounds in the Al-Si-Cu system. In: Acta Microscopia, Vol. 12, pp. 77-82.

[9] LI, R. (1996). Solution heat treatment of 354 and 355 cast alloys. In: AFS Transaction, Vol. 26, pp. 777-783.

[10]PARAY, F., GRUZLESKI, J. E. (1994). Microstructure - mechanical property relationships in a 356 alloy. In: Cast Metals, Part I. Microstructure, Vol. 7, pp. 29-40.

[11]CACERES, C. H., SVENSON, I. L., TAYLOR, J. A. (2003). Strength-ductility behaviour of Al-Si-Cu-Mg casting alloys in T6 temper In: International Journal of Cast Metals Research, Vol. 15, pp. 531-543.

[12]WANG, Q. G., APELIAN, D., LADOS, D. A. (2001). In: Journal of Light Metals, Part II - Effect of microstructural constituents. Vol. 1, pp. 85-97.

[13]HURTALOVÁ, L., TILLOVÁ, E. (2013). Elimination of the negative effect of fe-rich intermetallic phases insecondary (recycled) aluminium cast alloy. In: Manufacturing technology, Vol. 13, No. 1, pp. 44- 50. 
[14]TAYLOR, J. A. (2004). The effect of iron in al-si casting alloys. In: 35th Australian Foundry Institute National Conference, Adelaide, South Australia, pp. 148-157.

[15] MOUSTAFA, M. A. (2009). Effect of iron content on the formation of B-Al5FeSi and porosity in Al-Si eutectic alloys. In: Journal of Materials Processing Technology, Vol. 209, pp. 605-610.

[16] SEIFEDINE, S., JOHANSSON, S., SVENSSON, I. (2008). On the Role of Copper and Cooling Rates on the Microstructure, Defect Formations and Mechanical Properties of Al-Si-Mg Alloys. In: Materials Science and Engineering A, Vol. 490, pp. 385-390.

[17]TILLOVÁ, E., PANUŠKOVÁ, M. (2008). Effect of solution treatment on intermetallic phase's morphology in alsi9cu3 cast alloy. In: Mettalurgija/Metabk, Vol. 47, No. 3, pp. 207-210.

[18]LI, R. X., LI, R. D., ZHAO, Y. H., HE, L. Z., LI, C. X., GUAN, H. R., HU, Z. Q. (2004). Age-hardening behaviour of cast Al-Si base alloy. In: Materials Letters, Vol. 58, pp. 2096- 2101.

[19]WANG, E.R., HUI, X.D., CHEN, G.L. (2011). Eutectic Al-Si-Cu-Fe-Mn alloys with enhanced mechanical properties at room and elevated temperature. In: Materials and Design, Vol. 32, pp. 4333-4340

[20]European Aluminium Association. Aluminium Casting Techniques - Sand Casting and Die Casting Processes. http://www.azom.com/article.aspx?ArticleID=1392\#_Gravity_Casting, Available on-line 18.08.2015

[21]HURTALOVÁ, L., TILLOVÁ, E. (2009). Dissolution and melting of AL2Cu phase particles in recycled AlSi9Cu3 cast alloy. In: Materials engineering $=$ Materiálové inžinierstvo. Vol. 16, No. 3a, pp. 110-115. 